\title{
Strong Disagreements West-Moscow on the Future of the World After World War II
}

\author{
Alban Malia \\ Universiteti Evropian i Tiranës
}

\begin{abstract}
The European continent after the end of World War II was completely destroyed. A destruction of such proportions was not even done in the 30-year War three hundred years ago, not even in the Napoleonic wars of the 19th century. Now the victors had to prepare the treaties. This did not turn out to be a simple task. For the first time the Council of Foreign Ministers of the victorious countries met in London from September 11 until October 2, 1945. The first problem faced by this council was the opposition of Soviet Foreign Minister Vyacheslav Molotov to accept France and China as allies. France was dissatisfied with the Soviet move and again felt excluded from major decisions. US President Harry Truman appealed directly to Stalin, but the latter did not respond. The Western allies proved determined. They would not allow any of their allies to be excluded from Soviet desires. This act was also the first disagreement between the Western foreign ministers and the Soviet foreign minister.
\end{abstract}

Keywords: WWII, treaties, decisions, alliance, desires.

\section{Introduction}

\section{London`s Conference 1945}

Disagreements between the West and the Soviet Union also came into conflicting views on the future of the Mediterranean and Eastern Europe, which Bevin as the representative of Great Britain has considered them as strategic areas for his country.

Molotov also considered areas of particular strategic importance to the Soviet Union. When it came to talking about Italy, Molotov demanded that the Soviet Union be given Libya in good faith, but he encountered Bevin's rejection. Molotov demanded that Yugoslavia must take the port of Trieste which was occupied by Anglo-Americans. Both Bevin and Burns (US Secretary of State) refused.

Bevin understood Stalin's game for the Mediterranean. He wanted as many safe harbors as possible in this space to play a key role in the Middle East and in Mediterranean. The UK could not easily allow it to be replaced in a strategic area for which it had invested for two centuries. But politics are relentless. The great powers have always replaced each other. British interests felt threatened from the Suez Canal to the oil fields of Arabia. While the UK sought to continue to be the first violin in the Middle East, the Soviet Union sought all of eastern Europe.

Molotov therefore rejected all Western arguments to allow a free process to choose the form of government in this area of Europe. Although coalition governments were formed in some Eastern European countries, the communists and pro-Soviet members of these governments were the real power. Even for Germany, no meaningful agreement was reached. Molotov repeated Stalin's request once again for the Ruhr area to be divided between the four occupying powers.

The Western allies rejected the demand, and in turn Molotov rejected their demand for free access to the Soviet occupation zone. The French used the Council of Foreign Ministers to request the Rhineland area to be detached from Germany and together with Saar to became part of the French economic system and Ruhr to be internationalized.

Neither with this french proposal they agreed. Being that they were unable to agree on fundamental issues, US Secretary of State Burns asked Molotov for a meeting of the three greats in Moscow in December. Molotov agreed with all of Bevin's objections. Even at the December meeting, the three foreign ministers did not find common language. The disagreements between them would culminate in the 1946 in the Paris Peace Conference. 
President Truman was not liking the secretary of state. He complained that Burns had not protested long enough in order to stop the Sovietization of eastern Europe, the deployment of Soviet troops in Iran, and Stalin's refusal to sign free floats in international waters. In outrage, the president writes to Burns" I got tired of spoiling the Soviets ".

The secretary of state took the message and would take a tougher stance after the meetings. Peace Conference held in Paris on April 15-May 16 and June 15-July 12, 1946, produced a series of peace agreements. This conference "allowed" Soviet troops to stay in Bulgaria, Hungary and Romania, recognizing Moscow as a dominant role in this part of Europe. For Germany it was discussed on 29 April, 15-16 May and 9-12 July 1946. With difficulties was agreed on the Essentials. Burns attempted to reach an agreement that would keep Germany unarmed for twenty-five years and thereafter under the guarantee of four powers. Bevini and French Foreign Minister George Bidoult backed their counterpart's proposal. But the Soviet foreign minister dismissed it as saying that Germany was already demilitarized. Seeing the refusal stubbornness of Minister Molotov, Burns was convinced that the Soviet foreign minister would reject any Western proposal. He suspected that Stalin was simply waiting for the Americans to leave Europe to take over the rest of the continent.

\title{
2. Further aggravation of disputes
}

Burns and Bevin rejected Molotov's proposals for a division between the four Ruhr powers because they did not want any part of Germany to be economically separated. Bevin feared a Soviet control of the Ruhr because if allowed, Stalin would get his hands on the whole area and economically control Germany and the rest of Europe. In order to withstand Soviet pressure, Burns and Bevin agreed to unite their German economic zones in accordance with the Potsdam agreement. Although Molotov was in principle for a German union, he rejected the proposal. Bido also rejected the Anglo-American proposal. Moreover, France was opposed to any kind of German unification after being attacked four times in 80 years. The United Kingdom and the United States required the Soviet Union to send food to its occupation zone which it had not done so far. They also accused Molotov that the BS had received reparations from Silesia and Königsberg. Disputes over reparations have continued since the Yalta meeting. Molotov spoke as if Stalin did not want long-term peace with Germany. At the July 10, 1946 meeting, Molotov argued that the Soviet Union would not be able to sign a peace treaty with Germany until the latter paid the remaining penny for years. Burns countered that such an ultimatum would make it possible that peace would never be reached with Germany and that the Soviet position would lead to a revision of US plans to leave Europe.

At the meetings of the four foreign ministers held after the close of the peace conference, political incompatibilities between the Soviet Union and the Western allies were once again highlighted. British Foreign Minister Bevin knew that words would achieve no results. He sought to reach an agreement.

He had complete freedom of action from Prime Minister Etlli, but British power was no longer the same of the 19th century. Bevin was an anti-Communist. He disliked Molotov and called him "Mowlotov-Mullartov" (mow). From these offensive positions, Stalin declared that Bevin was not noble. The British foreign minister was convinced that the Soviet Union at the London and Moscow meetings had simply gained time to consolidate its occupations in eastern Europe. Bevin also feared that the Soviet Union would sign the peace treaty with Germany.

\begin{abstract}
Although in principle he agreed with Bidos' position on the partition of Germany, he demanded that Western allies united into economic zones outside the Soviet influence. He saw this as the only way to keep American forces on the continent engaged. Bevin tried to persuade Burns to find an alternative to unifying Germany with Stalin. Soviet attempts to spy on the secret of the atomic bomb further reinforced Bevin's suspicions. It was clear that with the Soviet Union, co-operation would no longer be on the agenda. The world was de facto divided into two camps.
\end{abstract}

\section{Dividing Europe into two ideological parts}

Winston Churchill was, as always, the first to denounce the division of the world and especially of Europe into two camps with opposing ideologies. His famous speech in Fulton, Missouri, USA, in early March 1946, was harsh and overly fatal to the future of the world. He has stated that:

"From Stetin to the Baltic up to Trieste in the Adriatic, an iron curtain has descended on the continent. Police governments will take power in a large number of countries. Communist parties or the fitth columns will pose a growing challenge to Christian civilization. I do not believe that Soviet Russia requires war. What it wants are the fruits of war and the never-ending expansion of its power and doctrine.". 
Stalin was outraged and accused Mitchell of being a "warrior" who preached "racial theory" to which only English-speaking peoples had the right to decide the fate of the world. In fact, it was the Soviet Union that opposed any form of colonialism and was now seeking to establish its own ideological hegemony with the power of the bayonet. This harsh speech by Churchill was not welcomed by many US senators. They even went so far as they accused the former British prime minister of being an aide to Nazism after helping with his and the Conservative Party's policies to strengthen the Hitlerian regime. The fear of a new collision was being felt all over Europe. Would there be a war again?

\section{Stalin takes control of his occupation area}

The effort to decide together for the future of Germany was becoming more and more difficult. Political elections were obscuring diplomatic options. On the map, Germany no longer existed. The Nazi political and military apparatus had been wiped out. German society was destroyed. The winning allies helped. The three greats had not evenly divided the country. The US and Soviet areas had an area of $66,340 \mathrm{~km}$ with 17 million Germans each including millions of refugees. The British occupation zone covered an area of $97,000 \mathrm{~km}$, but possessed the entire Ruhr region which was also the economic heart of Germany with a population of 22 million. The French occupation zone occupied an area of $40,000 \mathrm{~km}^{2}$ with 5 million inhabitants and very few refugees.

The real Achilles heel for Germany was in the Soviet occupation zone. This was due to the fact that Stalin and his German associates had immediately started the revolution of the area and its gradual return to the communist system, a model that would serve all of Germany. The Soviet leader knew that one day he would have to deal with a resurrected Germany and he needed to be sure that the country had a social, economic and political system aligned with the Soviet Union. Stalin did not look at Germany with the eyes of Churchill and Roosevelt

or Etlli with Truman. Like the Soviet Union, Germany was also part of the European continent. Poland could have served as a division between the two states, but history has shown how easily the two countries could cross this divide to one another. Stalin loved and even demanded a united Germany. With the partition of Germany, he would remain the most undesirable part of the country. The Soviet occupation zone had very few assets. Geostrategically, it was connected only with Poland and a small part of the Baltic Sea. There was no need to tell the Soviet leader that his part did not exert any influence on the rest of Germany. This also naturally led to the lack of Soviet influence in Western Europe. Stalin's hope was to achieve German unity under the authority of the German Communist Party. His plan was simple, but it would be a great achievement. Initially, Germany had to become a state, even a bourgeois state, as it was in the era of the Weimar Republic. Socialist and Communist parties would exert their influence until the whole country became a leftist extremist. He began instructing Communist politicians to work closely with the Socialists and have the patience that with the time Germany would become Marxist.

\section{Dilemmas for the Germany unification}

Stalin saw the unification of Germany as a strategic necessity for the Soviet Union. Even a bourgeois Germany would be too good for him to pave the way for Stalin to influence all over Europe. At a meeting of the Political Bureau held at the end of May 1945, Stalin stated that: "It would be an utopia if we were hoping for the peasantry of German society ".

He wanted Germany to have good relations with the Soviet Union. For this reason he sent to Germany, Anastas Mikojan, his most loyal economic affairs man, to make a specification of the situation in post-war Germany and to recommend which economic path Germany should pursue to help the Soviet Union. With the issue of unity, the Soviet occupation zone had to serve as a basefor the spread of Soviet influence by the Germans Communists. In the summer of the year 1943, Stalin had founded the National Committee for the Free Germany, which immediately after the war turned into Moscow's political spokesman. The leader of this group was Walter Ulbricht. On April 30, 1945, two and a half months before the Potsdam conference, this committee had entered in Germany. Ulbricht was directly Stalin's man for Germany. Based on the guidelines of the Soviet Foreign Ministry, Ulbricht began doing a study of post-war Germany. Some other groups of German communists were distributed to other areas of the Soviet administration. As they had planned, they immediately began working to print a newspaper, set up a radio and a publishing house. With the authorization of the Soviet authorities, they were transformed into trade unions and immediately began working the next day as administrators of the country.

The Soviets and Ulbricht made sure that all the staff of this union were made up of Germans who had lived in the Soviet Union or were his sympathizers. The contacts Ulbricht had in Germany greatly helped to select people and expose Nazi collaborators. Ulbricht's motto was: 
" Everything must look democratic, until we have all the things in our hand ".

On July 14, 1945, under the orders of General Georgiy Zhukov, the members of this union began to exert strong influence to unite all the German people around them. In the choice of Walter Ulbricht as his man to run Germany, Stalin had chosen a man like himself. Ulbricht was missing the popular support, but he knew how to take power. He was not a prominent speaker, but he knew how to organize the work. German policy was not unknown to him. During the years of the Weimar Republic, he had been a member of parliament as a member of the Communist Party. When Stalin had tried to shape the idea of the German Communist Party in the 1920s, he had relied on Ulbricht's allegiance. Ulbricht had left Germany when Hitler came to power. Initially, he had gone to France and then briefly participated in the Spanish Civil War. The Soviet apparatus had identified it as a potential leader for German communism. The Soviet Secret Service brought him to the Soviet Union where he spent the entire period of World War II. There he became a member of the Comintern. No one knew the German Communist Party better than Ulbricht. He was Stalin's right man. Stalin and Ulbricht began working immediately as soon as Germany surrendered. They launched a wide-ranging plan for the nationalization of industry in the Soviet occupation zone with the claim that everything that belongs to the Nazis had been taken. In mid-1946, a private property no longer existed in the Soviet occupation area. From his area, Stalin took what he could to bring it to the Soviet Union. More than a thousand factories were dismantled and all German technology shipped to the Soviet Union. The technological capability of the Germanic area under Soviet occupation had ceased to exist. Ulbricht had hoped that the Germans would support this reform, but it was quite the opposite. When it is related to the interest, nobody forgives. Seeing the savagery with which the Soviets were dealing (mass rapes and expropriations), thousands of Germans in the Soviet zone were migrating to areas administered by Western allies. Under Stalin's pressure, Ulbricht had to take vigorous measures to stop emigration.

Despite the great help, Ulbricht realized that communism could not triumph in Germany. Even in Austria and Hungary, the Communists performed poorly. Stalin was not happy with the situation. Many Social Democrats refused to merge with the Communist Party. The respected Social Democrat leader Kurt Shumaker came out against it. But under Stalin's pressure, the social-democratic leader of the Soviet occupation zone Otto Grotevohl did not resist. Despite President Schumacher's objections, Grotevohli declared the merger of the Social Democratic forces with the Communist Party in the Soviet occupation zone. According to German commentator Wolfgang Leonhard who was a communist himself, this merger had dictatorial tendencies.

For the Western Social Democrats of the Allied occupation zones, it was easy to identify Grotevohli as a traitor. They did not take into account the terrible pressure the area's social-democratic leader was facing. On September 20-24, 1947, the second union convention (the first convened in April 1946) was called where out of the twenty-two speakers, only two belonged to the Social Democratic Party. Officially the SPD in the Soviet occupation zone no longer existed.

\section{Conclusions}

It was impossible for the Soviet and German Communists to win the people's sympathy. The Soviet army had entered in Germany from eastern Prussia and Silesia. The terror campaign had been terrible. Soviet soldiers were inspired by the words of Marshal Zhukov:

\section{" We will take revenge in a terrible way for everything ".}

Rape became the most widespread crime of Soviet soldiers in their area of occupation. Although there were Soviet officers who tried to stop this thing, even firing soldiers, they gave up as the hatred of the Soviets towards the Germans could not be stopped. Seeing the importance of the situation, Pravda newspaper recalled a Stalin article on February 23, 1942 :

"It would be ridiculous to identify the German people with Hitler. Historical experiences have shown that the Hitlers come and go, the German people and the German state remains ".

Marshal Zhukov gave a firm order to maintain discipline, but the damage had already been done. According to statistics in the following years, more than two million German women of all ages were raped by Soviet soldiers. Despite these growing problems, Stalin and Ulbricht began to disagree on political issues. Stalin wanted to exert fear on the German population and could remove Ulbricht's authority with a swipe of his finger, but strangely he never discharged his trustee. Ulbricht too had mastered the art of deception to such a degree that he could throw it at Stalin, but again the Soviet leader did not 
dismiss it. Ulbricht's ability to pursue policies, somewhat independent of his boss remains one of the biggest mysteries of international relations and post-war German history.

\section{References}

[1] Smyser, From Yalta to Berlin

[2] Wheeler-Bennett and Nicholls, The Semblance of Peace: The Political Settlement after the Second World War, New York: Norton, 1974.

[3] James F. Byrnes, Speaking frankly, New York, Harper \& Brothers, 1947

[4] Wheeler-Bennett and Nicholls, The Semblance of Peace

[5] Oliver Stone, \& Peter Kuznick, The untold history of the United States, London: Ebury Press, 2012.

[6] John Lewis Gaddis, We now know, Oxford: Clarendon Press, 1997.

[7] David Childs, The GDR: Moscow's German Ally, London: George \& Unwin, 1983.

[8] Ruth Fischer, Stalin and the German Communism, Berlin: Dietz, 1991. 